\title{
A MAGYAR MEZŐGAZDASÁG KÖRNYEZETI ÉS REGIONÁLIS PROBLÉMÁI
}

\author{
(Environmental and regional problems of the Hungarian agriculture)
}

\author{
SÁNTHA ATTILA
}

\section{A hagyományos gazdálkodási modell jellemzői és környezeti hatása}

Az ország megkésett gazdasági fejlődése az agrártermelés színvonalára is rányomta a bélyegét. A nơvekvő népesség ellátására a húszadik század elejéig megtőrtént a müvelésre alkalmas területek vízrendezése és mezőgazdasági müvelésbe vonása. A mezőgazdaság belterjességének nơvekedését a szántófôld és a kert-gyümőlcsős mủvelési ágba, valamint a szőlötermesztésbe vont területek nővekedése, továbbá a hagyományos parlagi állatfajták (szürke marha, racka juh, mangalica disznó) fokozatos háttérbe szorulása jelezte. A századfordulóig tartó és a mezőgazdaságra is jelentős hatást gyakorió gyors gazdasági fejlödés az I. világháborúval megtőrt. A mezógazdaság elvesztette a kరzzvetlen külsỏ piacait, az alacsony életszínvonal miatt a belső fogyasztás is stagnált, a nyomott árak mellett a mezógazdasági termékekból egy tartós kínálati helyzet alakult ki. A piac és a tőkehiányos ipar lassú fejlődése nem biztosított elegendő munkahelyet, így a mezőgazdaságban jelentős nagyságú rosszul képzett, alacsony fokon hasznosított munkaerö vegetált. A helyzetet még rontotta a fóld szélsőséges tulajdoni megoszlása, amelyet legjobban az mutat, hogy az 500 katasztrális holdnál nagyobb fóldterülettel rendelkezö 3123 fóldbirtokos - a földbirtokosok $0,27 \%$ - a - tulajdonában volt a foldterület $32,7 \%$ - a, míg az 5 katasztrális holddal vagy annál kisebb területtel rendelkezó 674414 kisbirtokos - a foldbirtokosok $58,7 \%$-a csupán a foldterület $8,9 \%$-át birtokolta. A rossz piaci lehetőségek, az alacsony termelöi jővedelmek, valamint az olcsó munkaerő túlkínálata nem tette lehetővé a mezỏgazdaság egészében a termelés modernizációját, így - egyes mintagazdaságokat leszámítva - a termelés alacsony eszkőzráfordítással, alapvetően az élőmunkára alapozva folyt (a mezőgazdaság foglalkoztatta 1950-ig a népesség tőbb mint $50 \%$-át), ennek megfelelően fajlagosan kis élömunka és területi hatékonyság mellett. A vonóerő tőbb, mint $90 \%$-át állati vonóerő szolgáltatta, az I ha mezőgazdasági területre jutó mưtrágya-hatóanyag felhasználás pedig 1938-ban is még csak $2 \mathrm{~kg} / \mathrm{ha}$ volt. A mintának tekintett Dániától az országot 2-3 évtizedes lemaradás választotta el, annak ellenére, hogy ezzel a teljesítményével is az ország Európa kőzépmezönyében helyezkedett el, mutatói meghaladták a dél- és kelet-európai országok teljesítményét.

Mivel a háború után, lényegében 1960-ig - bár változó mértékben - radikális tőkekivonás ment végbe a mezógazdaságból, amely az iparfejlesztés megindulásával, már je- 
lentős munkaerő elvesztésével is járt, a termelés a lassan növekvő gépi vonóerö és mütrágya felhasználás ellenére (1960-ban $23 \mathrm{~kg}$ /ha) lényegében stagnált, a termelési technológia terén tovább nőtt az ország elmaradottsága a nyugati fejlett országokkal szemben. Így lényegében az 1960-as évek elejéig életben maradt az a hagyományos mezögazdasági modell, amelyet a fejlett nyugat-európai országokban már az első világháború után meghaladtak. Ennek egyik alapvető jellemzöje volt - az ipari eszközök hiánya és drágasága miatt - az ipari inputok alacsony felhasználása. Mivel az ágazat külső eröforrásokra csak korlátozott mértékben támaszkodhatott, ezért teljesítményét az határozta meg, hogy a rendelkezésre álló erỏforrásokat hogyan tudja hasznosítani. Ezért minden terméknek a teljes körü hasznositására törekedtek még a melléktermékeket (pl. szalma, kukoricaszár, trágya) is vagy takarmányozásra vagy almozásra, vagy pedig trágyázásra, illetve tủzelésre használták fel és lényegében nern ismerték a hulladék fogalmát. A melléktermékeknek az ökológiai ciklusokhoz hasonló, a talajtól a talajig tartó zárt forgalma mai szempontból rendkiviül pozitívan ítélhetó meg, mert lényegében a termelés viszonylag alacsony környezeti terhelés mellett folyt.

Ennek ellenére - elsősorban a szegénysége miatt - nem tekinthetó ez a termelési modell ökológiai szempontból optimálisnak, mert a szalag parcellák hegy-völgy irányú múvelése hozzájárult a talajok eróziós pusztulásához, nagy térségekben a termőréteg lekopásához és az alacsony színvonalú tápanyag utánpótlás miatt pedig a talajok tápanyag készletének csökkenéséhez. A rosszul kezelt trágyakazlak szennyezték a talajt, a talaj-és a felszíni vizeket, továbbá az élelmiszerek (pl. tej) higiénikus kezelésének feltételei sem voltak meg. Ez a termelési mód gazdasági szempontból is tarthatatlanná vált, mert a külső inputok hiányában termelés növelésére csak nagyon kis lehetöséget nyújtott (pl. a búza átlaghozama 1938-ban és 1960-ban is 1,6 t/ha volt) és rendkívül magas volt a termelés élómunka igénye.

A rossz infrastrukturális feltételek, a magas szállítási költségek arra kényszerítették a termelöket, hogy a termelési szerkezetük kialakitásakor elsősorban a helyi piaci lehetöségeket és a helyi termelési adottságokat vegyék figyelembe. Így alakultak ki a nagyvárosok kömyékén a zöldség- és gyümölcstermelö körzetek, mig távolabb általában szántóföldi kultưrákkal és állattenyésztéssel, szőlö- és bortermesztéssel foglalkoztak. Így a természeti adottságok és a piaci és szállítási lehetöségek fủggvényében nagyon sokszínü, egymástól eltérỏ termelési körzetek alakultak ki, amelyet a hagyományok is jelentösen befolyásoltak. Ez utóbbi jól megfigyelhető volt pl. Pécs környékén, ahol az egymás mellett lévő magyar, horvát és német nemzetiségi falvak termelési szerkèzete, a piacra vitt áru összetétele jelentősen eltért egymástól. Például a horvát falvakban nagy mértékben termesztették a gyökérzöldségeket és a káposztát, valamint a tarlórépát, a magyar falvakból inkább paradicsomot, paprikát, uborkát és tejet, a német falvakból pedig tejetés gyümölcsöt vittek a piacra. A várostól távol lévő hegyi falvakban a szarvasmarhatenyésztés, az Ormánságban a víziszárnyas (toll) - és sertéstenyésztés volt a legfontosabb ágazat stb.

A tájtermesztésben külön kategóriát képviselnek azok a több évszázados múltra viszszatekintő szölö - bor, és zöldségtermö tájak, amelyek nemzetközi hírnevüket az átlagosnál jobb természeti és gazdasági adottságok mellett, a piacok által nagyra értékelt fajták meghonositásának, illetve sajátos minőségủ tájfajták kialakulásának köszönhették (pl. a tárolást és szállítást jól elviselö makói hagyma). 
Sántha Attila : A magyar mezőgazdaság környezeti és regionális problémái

Tér és Társadalom 10. évf. 1996/4. 51-60. p.

\section{Az iparszerũ gazdálkodási modell kialakulása és környezeti hatása}

A mezőgazdaság nagyuizemi átszervezése után megkezdődött a mezőgazdasági termelés iparszerủ modelljének kialakítása. A gyors ütemet az indokolta, hogy a mezőgazdaság átszervezésével egyidejúleg elvesztette a munkaeró állományának jelentős részét és a korábban a kisüzemekben használt eszkőztömeg szinte egyik évről a másikra, a nagyưzemek létrejöttével használhatatlanná vált. 1959 és 1969 között a mezőgazdaságban foglalkoztatottak száma 700 000-rel csökkent, a mezőgazdaságban dolgozók aránya pedig 41\%-ról 25\%-ra mérséklödőtt, és ezzel főleg az őszi munkacsúcsok idején jelentős munkaerő hiány alakult ki. A mezógazdaság fejlesztésének másik indoka volt a lakosság olcsóbb hazai élelmiszerrel történó ellátása (1965-ig jelentós volt a gabona és húsimport), valamint az iparfejlesztés növekvő energia, gép- és nyersanyag igényének kielégítése érdekében a mezógazdasági termék export fokozása. Megoldást a termelés gyorsütemü mủszaki fejlesztése jelenthette csak. Az ehhez szükséges modellek és eszközök azonban sem hazai, sem pedig szocialista relációban nem álltak rendelkezésre, ezért hosszú próbálkozás után végül az amerikai farm modell meghonosítására került sor. Ezzel a nagyüzemekben gyors ütemben elkezdődőtt az ún. iparszerü termelési modell kialakítása, amely egy olyan árutermelö modell, amely rendkívül nagy mértékben támaszkodik az ipari eredetủ inputokra, teljesítményét alapvetően ezek mennyisége és minösége határozza meg, az ipari eszközök viszonylagos olcsósága miatt azonban egyidejüleg leértékeli azokat a belső üzemi kapcsolatokat (pl. melléktermékeket), amelyek a hagyományos termelés környezetkíméló és takarékos jellegét biztosították. Ezzel lépett át a mezögazdaság a manufakturális korszakból az ipari tömegtermelés korszakába, annak minden pozitív és negatív következményével együtt.

Minden termelési modellvăltás áldozatokkal jár. A kérdés az, hogy az előnyök menynyire haladják meg és egyáltalán meghaladják-e azokat a társadalmi áldozatokat, amellyel a modellváltás járt. Az iparszerủ modeli az átlaghozamok gyors ütemú növelésével a mezőgazdasági terméshozamokat másfél évtized alatt megduplázta, a mezögazdasági termelést a fejlett régiók színvonalára emelte. A termelési rendszerek és a háztáji integráció hozzájárult az egész mezögazdasági termelés gyors ütemú modernizációjához. A müszaki fejlesztés munkaerő felszabadító hatása lehetővé és egyben szúkségessé tette a mezögazdasági üzemek számára a kiegészítö tevékenységek fejlesztését és ezzel a mezőgazdasági térségekben az ipar meghonosítását. A '80-as évektől kezdve, a mezögazdasági tủltermelés általánossá válásával és egyben a mezőgazdasági termékek piaci leértékelödésével a kiegészitỏ tevékenység a legjobb jövedelem termelö tevékenységgé vált. Ezzel egyidejủleg viszont erősen nött az agrár ágazat ipari függése (pl. a mezőgazdasági területre kivitt nővényi tápanyagok $85 \%$-át a mútrágya szolgáltatta), az ipari eszközök felhasználása a korábbi szint 5-10-szeresére növekedett (pl. a mútrágyahatóanyag felhasználás kb. $20 \mathrm{~kg}$-ról 220-240 kg-ra), sokszorosan meghaladva a terméshozamok növekedésének a mértékét. Az ipari anyagok és eszközök növek̉ő és sokszor egyoldalú felhasználása egyre súlyosabb terhelést jelentett a környezetre. Ezek jelentős része megfelelö körültekintéssel jórészt ellensúlyozható lett volna és bár nem okoztak megfordíthatatlan károkat, összességében a természeti elemek leértékelése és a melléktermékek hasznosításának elhanyagolása a gazdálkodásban jelentős költségnöve- 
kedéssel és a természeti elemek károsodásával járt. A talajok esetében legfỏbb gondot a megfelelő körülttekintés nélkül (pl. lejtős területeken is) kialakított nagy táblák okozták, amelyek a szél (defláció) és a víz (erózió) okozta károk növekedését eredményezték. Ezek jelentős mértékben mérsékelhetők lettek volna az elhanyagolt területek beerdősítésével, a szervestrágyázás növelésével, a körulltekintó szervesanyag-gazdálkodással, a tőmörödött talajok mélylazításával, a savanyodó talajok mésztrágyázásával, a múvelési eszközők (pl. lejtős területek tárcsázása) és a müvelési irány jobb megválasztásával. Ezekre azonban csak az éves eredményekre koncentráló gazdálkodási gyakorlat nem fordított figyelmet. İgy miközben a magas színvonalú mütrágya felhasználás hatására növekedett a talajok tápanyag ellátottsága, ezzel egvidejúleg csökkent a talajok humusztartalma, romlott a vízgazdálkodása, pH-ja és növekedett az erózió és defláció kártétele.

A mütrágya felhasználás során nem a felhasznált mennyiség, hanem a mútrágyák helytelen tárolása, a nem megfelelő módon és időben történő felhasználása, és a nem megfelelő mütrágya választék jelentette az alapvető gondot és okozott kárt, mindenek előtt a talajok fokozott elsavanyodásával, illetve a felszíni és a felszín alatti vizek nitrát és foszfát tartalmának növelésével.

Az iparszerú termelés a legtőbb kárt a természeti elemek szerepének leértékelésével és a termelés növelésével egyidejüleg növekvő mennyiségủ melléktermék hasznositásának elmulasztásával okozta. Ez mutatkozott meg az állattenyészésben is, ahol egy-egy telepen teljesen mesterséges, természetellenes körülmények között (zárt, ablaktalan klimatizált épületek) elhelyezett állatok trágyáját vízzel egyszerủen a telepen kívül kialakitott tárolókba mosatták, ahol az a környezetet (talajt, talajvizet) szennyezte. Az iparszerü gazdálkodás annál nagyobb kárt okozott minél hosszabb ideig alkalmazták és minél teljesebb mértékben bontakozott ki. Magyarországon az előny meghaladta a kárt, mert viszonylag rövid ideig (alig több mint két évtizedig) alkalmazták, illetve az ipari termékeknek a mezőgazdasági termékekben viszonyított ára mindig kedvezőtlenebb volt, mint a nyugati országokban és igy az a felhasználásukat korlátozta.

A fỏldek kedvezỏ hasznositását a földszerzési korlátozás és az ezáltal kialakított kizárólag kisưzemekre és nagyưzemekre tagozódó ủzemi rendszer akadályozta, mert fékezte a nagyüzemi módszerekkel nem mủvelhető területek hasznosítását. Ezért ezek, bár méretük elérte a nagyủzemek területének 10-15\%-át, müveletlenül maradtak és leromlottak, fekvésüktöl fưggően elmocsarasodtak (régi kaszálók), illetve beerdősültek (legelök, szántók, szőlök). Ez a folyamat gazdasági értelemben kétségtelenül kárọs volt, de természetvédelmi szempontból ez sok ecetben nem mondható el gyakran, mert ezeken a területeken olyan ritka fajok telepedtek meg és szaporodtak el, olyan speciális ökoszisztémák alakultak ki, amely indokolttá tette azok természetvédelmi oltalom alá helyezését. Ez azonban nem javitotta az agrártáj képét, amelyre az volt a jellemzö, hogy jól müvelt, esetenként túlmúvelt nagy táblákat teljesen elhanyagolt területek határolták.

Az agrártérségek környezeti leromlását az is fokozta, hogy a mezögazdaság nem csak kiváltója volt sok esetben a környezet leromlásának, de egyben elszenvedöje is a más ágazatok által okozott környezeti károknak. Az ipar, a kőzlekedés és a kommunális szektor által okozott lég-, víz- és talajszennyezés egyaránt a mezőgazdasági termelés termelési feltételeit rontotta, hozamait csökkentette.

A háború utáni élelmiszerhiány, a kủlső piaci kapcsolatok megszakadása, majd a beszolgáltatási és tervrendszer uniformizáló hatása, a mezőgazdasági népesség gyors csök- 
kenése, a kialakuló nagyưzemek kezdeti nehézségei, az értékesítés és az árak központi szabályozása nem kedvezett a tájtermelés fejlódésének. Így az adottságoktól függetlenül a termelési szerkezet egyre uniformizáltabbá vált. Ebben a helyzetben lényeges változást a mezógazdasági nagy- és kisủzemek megerősödése, a termelésben a gazdasági kỏvetelmények elótérbe kerülése, a külpiaci kapcsolatok erösödése okozott, amely a fó mezógazdasági termékek mellett egyre nagyobb igényt támasztott a speciális mezógazdasági termékek (füszerpaprika, vöröshagyma, bor, aprómagvak stb.) iránt és ez sok esetben a régi tájtermelés megerósỏdését, újjáéledését eredményezte. $\mathrm{Ez}$ sokkal inkább jellemzó volt a növénytermesztésre, főleg a kertészeti termékek termelésére, mint az állattenyésztésre, ahol bár a régi termelési körzetek nem szúntek meg teljesen, de a termelés lényegesen kiegyenlítettebbé vált. Ebben jelentôs szerepet játszott az, hogy a központi élelmiszeripari beruházásoknál bizonyos területi kiegyenlítỏdésre tőrekedtek. $\mathrm{Az}$ élelmiszeripari beruházások (fóleg a konzervgyárak, hủtơházak, baromfifeldolgozók) önmagukban is ủj termelési körzetek kialakulását eredményezték. Jellemzó volt továbbá, hogy egy-egy meghatározó jelentőségủ mezőgazdasági nagyưzem a maga integrátori tevékenységével újabb termelési körzetek kialakulását eredményezte (pl. a bólyi és a bábolnai állami gazdaság, valamint a baksai tsz tojótyúk és pecsenyecsirke integrációja). Az értékesítési lehetóségek szabadabbá válása, továbbá a piaci lehetöségek bővülése is újabb termelési körzetek kialakulását eredményezte, amelyre legjobb példa a tiszántúli hajtatásos zöldségtermesztés és az ormánsági dinnyetermesztés.

\section{A jelenlegi helyzet és fejlesztési feladatok}

A mezőgazdasági termékek értékesítési lehetőségeinek, valamint az ipari és a mezögazdasági termékek árarányainak romlása gazdasági oldalról, a szigorodó környezetvédelmi követelmények pedig környezeti szempontból az alkalmazott iparszerü termelési modell módosítását követelték meg. Világszerte elötérbe került az anyag- és eszköztakarékos és környezetkímélö termelés, amelynek lényeges feltétele a helyi adottságok körültekintöbb figyelembevétele, valamint a költségtakarékos és az ipari eredetú inputok nélkül is hozamnövelést okozó hagyományos agrotechnikai módszerek (pl. elővetemény hatás, szervestrágyázás stb.) fokozott alkalmazása, az iparszerủ termelésben hulladékként kezelt melléktermékek (pl. szerves trágya, szalma stb.) jobb hasznosítása. Az agrártermelés fejlődésének fỏ irányát a múszaki fejlesztés eredményeit változatlanul hasznosítani kívánó integrált termelés, illetve a mủszaki fejlesztés eredményeit csak bizonyos fenntartással hasznosító biotermelés jelentette. Mind a két fejlesztési irány kialakulásához biztos piaci kapcsolatokra és jelentơs tőkére volt sziikség.

A magyar mezỏgazdaság fejlódési dinamikaja az állandósuló piaci zavarok, valamint a fejlesztést lehetetlenné tevó központi tőkeelvonás kővetkeztében a '80-as évek kőzepére megtört. A termelés a '80-as évek végéig lényegében stagnált és megkezdódött a korábban felhalmozott tóke felélése. Így termelési modellváltásra nem kerülhetett sor, a termelés továbbra is iparszerü módszerekkel, de a leamortizálódó eszközállománnyal egyre rosszabb feltételek között folyt. A '90-es években viszont elkezdődött a mezőgazdaságnak a századunkban egyedülálló mértékủ válsága, amelyet a termelés közel 40\%os visszaesése, a fejlesztések minimálisra csökkenése jelez. A kárpótlási és privatizációs 
folyamattal egyébként is szervezeti és tulajdoni válságba került ágazat a belsỏ és külsỏ piacainak jelentós részét elvesztette és teljesen kiszolgáltatottá vált a piaci és pénzügyi manipulációkkal szemben, amely révén pár év alatt korábban elképzelhetetlen mértékú tőkekivonás ment végbe az amugyis tőkehiányos ágazatból. A visszaesés mértékét nemcsak az állatállomány közel 50\%-os csökkenése, a termelésnek és a terméshozamoknak kb. 40-50\%-os visszaesése jelzi, de az is, hogy a beruházások az 1989-es érték 13\%-ára (1992), a mütrágya felhasználás pedig 20\%-ára esett vissza.

Jelenleg legfóbb gondot a pontos információk hiánya jelenti. Az köztudott, hogy a termőföld kb. 85\%-a magánkézbe került kb. 1 millió ha erdó és 28 kincstári birtok terìletének kivételével, de ismeretlen, hogy a fỏld a kb. kétmillió tulajdonos között hogyan oszlik meg és hogyan alakulnak a föld tulajdon és a használati viszonyai. Az a tapasztalatok alapján leszürhető a fòld $\mathrm{kb} .60 \%$-át ma is nagyüzemi módon mủvelik és az árutermelés dőntő része is a nagyüzemekböl ( $\mathrm{kft}$., rt., betéti társasság, szövetkezet) származik. A tulajdonba került föld dỏntő többségét bérleti formában múvelik. A hivatalosan nyilvántartott magángazdaságok száma kezdetben 1994-ig gyorsan nőtt, majd pedig jelentős mértékben csökkent, ami a gazdálkodás kudarcaira utal. A tapasztalatok szerint falvanként egy-két olyan magángazdaság alakult ki, amely számottevö fejlödésre és bövủlésre képes, fóleg azok, amelyek már korábban is jelentős árutermelést folytattak, illetve kedvezó pénzủgyi feltételekkel indultak. Kétségtelen tény, hogy a fóldtulajdon szélsőséges szétaprózódása egy szélsőséges méretú koncentrációra teremti meg a feltételeket. A kincstári birtokok mellett a gazdasági társaságok és szövetkezetek $\mathrm{kb}$. egyharmada rendelkezik olyan anyagi és szellemi kapacitással és piaci kapcsolatokkal, amely a fejlödés feltételeit magába hordozza.

A mezógazdaság általános elszegényedése látszólag javuló környezeti állapotokat teremt, mert fékezi azt a nyomást amit az ipari eszközök növekvó felhasználása okoz, illetve okozott. A helyzet azonban nem ilyen egyszerü, mert egy gazdálkodási modellváltást az iparszerúból az integrált - vagy biotermelésre való átmenetet csak folyamatos fejlesztéssel és képzéssel együtt lehet végrehajtani, amelynek feltételei egyáltalán nem állnak rendelkezésre.

A fóldtulajdon körüli bonyodalmak, a mezógazdaság elszegényedése rendkívüli módon leértékelte a földet és a spekulációs célú földszerzések erös nyomást jelentenek a földnek a termelésból való kivonására, így nagyon értékes termỏhelyek megszúnésére kell számítani, fỏleg a nagyvárosok és a Balaton környékén. Jelenleg a föld minőségének megóvása is másodlagos kérdés lett. A romló eszközállomány miatt sok a rosszul mủvelt föld, jelentős részük pedig mủveletlenül maradt. A töbọnyire egy vagy csupán néhány évre szóló folldbérletek nem ösztönöznek a talaj védelmére. Az erózió, defláciỏ kérdésével, a földek lassú elsavanyodásával, elszegényedésével ma senki sem foglalkozik.

A gazdálkodásban a minimális befektetés és a biztos értékesítés a fó szempont. Ebböl adódik az, hogy szinte trágyázás (az is szinte kizárólag mútrágya) nélkül és hiányos nỏvényvédelemmel múvelt teruletek terméshozama nemcsak lecsökkent, de az idójárási körülményektől függően szélsőségesen ingadozik. A földek elgyomosodtak és a legkisebb kockázattal termelhető növények, köztük elsősorban a gabonafélék váltak mindenütt meghatározóvá. Jelentős kárt okoz az, hogy az állatállomány csőkkenése miatt a 
takarmánynövények, köztük az évelő pillangósok termelése folyamatosan visszaszorul, igy kevésbé érvényesül ezeknek a növényeknek a talajkondicionáló és védő hatása is.

A kemizálás visszaesése bár kétségtelenủl környezeti előnyökkel is jár, ezt azonban a károk és a növekvő termelési és egészségügyi kockázatok bizonyára meghaladják. A mútrágyázás visszaesésével a termelés már több mint fél évtizede a korábban a talajban felhalmozott tápanyag tőkét éli fel, amit még a szervestrágyázás visszaesése és a talaj tápanyag készletét gyarapító pillangósok termelésének jelentős csökkenése is fokoz. A növényvédelemben - a növekvő termelési veszteségek mellett - a legfőbb gondot a növényvédỏ szerek forgalmazásánál és felhasználásánál a korábban megkövetelt fegyelem és szakértelem megszúnése okozza. Az ellenörizetlenủl forgalomba kerülö különbözó (sokszor ismeretlen összetételủ és hatástartalmú) szerek szakértelem nélkül történő felhasználása jelentỏs humán- és állategészségügyi kockázattal jár. Sok esetben a kialakult keskeny parcellák, a leamortizált növényvédỏ gépek még kellő szakmai ismeret mellett is a szakszerủ növényvédelem alkalmazását lehetetlenné teszik.

$\mathrm{Az}$ állattenyésztés terén a müködỏ telepek rossz állapota, a falvakban a kis telkeken esetenként kialakult intenziv tej - illetve sertéshústermelés a lecsökkent állatlétszám ellenére jelentős terhelést jelent a környezetre.

Ami a mezógazdaságban van az nem más mint az iparszerủség romja, ami igazán az iparszerủségből megmaradt az a mechanikus, a melléktermékeket, a természeti tényezőket leértékelő gazdálkodási szemlélet, amely a kis- és nagyuizemekre egyaránt jellemző. Ennek a kōvetkezménye a szerves trágya hanyag kezelése és felhasználásának elmulasztása, a tarló és szalma égetés fokozott mértékben történő alkalmazása, mindenütt az uniformizált termelési technológiák alkalmazása. A szerencsétlenség az, hogy miközben . nyugaton a minden szakaszában ellenörzött termelés ma már általánossá válik, addig nálunk sok esetben a tehénfogat színvonalára esett vissza a termelés, így a mezógazdaságunk mennyiségi és minöségi tekintetben elveszti a versenyképességét, súlytalanná válik.

A reménykeltỏ csupán az, hogy az országban kialakultak azok a különbözó szervezeti formák és termelés technológiai modellek, amelyek kedvező közgazdasági feltételek mellett lehetóvé tennék a korszerủ módszerek gyors elterjedését és a termelők keresik is a fejlesztés perspektivikus lehetőségeit. Ennek azonban jól körülhatárolható feltételei vannak.

A mezőgazdaság értékesítési válsága, nagy térségekben a feldolgozó ipar ősszeomlása (baromfi, konzerv, bor- pezsgő, húsipar stb.), a háztáji integrációk felbontása nemcsak a termelés általános visszaesését, de sok esetben a kialakult termelési körzetek megszünését is eredményezte. Erröl pontos adatokkal ma még nem rendelkezünk. Az viszont közismert, hogy a mezőgazdasági termelés alacsony jövedelmezósége, a bérleti dij megjelenése felértékelte a jobb adottságú területeket és egyidejüleg leértékelte a rossz adottságú térségeket. Ezt egyébként a parlag területek magas aránya és annak elhelyezkedése is jelzi. Kétségtelen, hogy az éles piaci verseny felértékelte a minóséget és az egyöntetú minőségi árutömeg, valamint a külpiaci kapcsolatok jelentőségét. A minőséggel függ össze pl. a tokaji, az egri és a villány-siklósi borvidékek növekvő piaci részesedése, valamint az alföldi borvidékek piacvesztése. A termelési körzetek kialakulásában (pl. tej, hús), fennmaradásában dőntő szerepet játszanak a sikeres nagy feldolgozók, amelyek a nagyủzemból nagy tömegben beszerezhetỏ termékeket részesítik elónybe 
a kisebb költségek és a garantáltabb minöség miatt. Elég általános ma már, hogy a feldolgozók a néhány tehenes kistermelök tejét már nem szállítják el. Teljesen új jelenség, hogy a nagy feldolgozók (pl. Zalahús, Délhús) az alapanyag szükségletük biztosítása érdekében nagyon sok gazdaság állattartó telepét felvásárolták, így a teljes termelési vertikumot kézben tartják.

A tájtermesztés egy tartós szakmai kultúrát jelent, amit viszonylag könnyü feltámasztani, ha az adott termékre kereslet van. Erre az elmúlt évben számtalan példa volt. Mindenképpen meghatározó azonban egy kellỏ tókeerövel és piaci kapcsolatokkal rendelkezö integrátor jelenléte. Az egyes borvidékek eltérö piaci szereplése is jórészt erre vezethetö vissza. A rendkívill gyorsan növekvő szállítási költségek, az emelkedő termelési kőltségekkel egyuitt a termelési körzetek átrendeződését fogják eredményezni. Erre jó példa az, hogy miközben a Nyírség almatermesztése teljes értékesítési válságban van, addig Zalában jelentös területeken hoznak létre intenzív almaültetvényeket, amelyek a nyugati piacokhoz és az ellátatlan Dél-Dunántúlhoz is közel vannak.

A gondok és okok ismeretében a feladatok viszonylag pontosan meghatározhatók. cEzek a következök:

- Gazdaságos és környezetkímélö termelés csak jelentös fejlesztéssel alakítható ki. A legszennyezöbb és a legpazarlóbb az alacsony múszaki színvonalon folyó termelés. A termelés jövedelmezőségének javitása, a termelés szélsöséges ingadozásának mérséklése érdekében mindenek elött nagyobb fokú központi piacszabályozásra van szükség, amely magába foglalja a termelés növeléséhez nyújtott állami támogatást épp úgy, mint a minimál árak meghatározását, a központi készletezés megoldását, valamint az aránytalan mértékben támogatott versenytársakkal szembeni belsỏ piacvédelmet.

- A hatékony termelés irányítás érdekében nagyon gyorsan rendezni kell a földtulajdon kérdését és a szabad földforgalom és a nemzetközileg versenyképes földkoncentráció létrejöttének elősegitése érdekében támogatni kell a szövetkezetek közös földtulajdonának és az osztatlan közös vagyonának a kialakitását, lehetővé kell tenni, hogy a mezőgazdasággal foglalkozó magyar tulajdonú gazdasági társaságok korlátlanul földet vásároljanak és a kincstári birtokok is visszavásárolhassák a telepeik körül kiprivatizált földeket. Ezzel részben ellensúlyozhatók azok a károk, amellyel az átgondolatlan privatizáció és a 0,5-1 hektáros parcellák müvelése (növényvédelme) jár.

- A föld védelme érdekében rendkívül fontos a bérleti viszonyok rendezése és a földbérletek legrövidebb idejének 3-5 évben történỏ meghatározása.

- A korszerü agrártermelés (az integrált- és a biotermesztés esetében egyaránt) magas müszaki színvonalon folyó, minden szakaszában, a szántóföldtől a fogyasztó asztaláig ellenörzött termelést jelent. Ennek érdekében a nagygazdaságoknál vissza kell állítani a három évenként kötelezö talajvizsgálati rendszert, javítani kell a növényvédelmi elörejelzést és kistermelés esetében a növényvédelmi szaktanácsadást. A talajvizsgálatok elvégzését és a szaktanácsadás igénybevételét minden egyéb támogatás feltêteléul kell szabni. Egyidejúleg gondoskodni kell a lejárt szavatosságú szerek és csomagoló anyagok visszagyüjtésérỏl.

A földek további leromlásának megakadályozása érdekében támogatni kell az elhanyagolt vizelvezető rendszerek, árkok rekonstrukcióját, a talajok további elsavanyodásának megakadályozása érdekében azok meszezését, valamint a túl kötött talajok mélylazitását. Az éghajlatváltozás ellensúlyozására folytatni kell a többcélú hasznosítást 
szolgáló tározók kialakítását, és támogatni kell az öntözhetỏ területek mértékének nővelését.

- A víz megtartása és a defláció fékezése érdekében pedig a kieső területek erdősítésére, fasorok telepítésére van szükség. Ezek az intézkedések egyben a természetes élövilág életfeltételeit is megteremtik, amelyre nemcsak a fajok megórzése érdekében, de a kőltségek csökkenése miatt is szükség van.

- A mezógazdasági területek leromlásának megakadályozása érdekében érvényt kell szerezni a müvelési kötelezettségnek. A kedvezőtlen adottságú térségekre pedig központilag támogatott erdőtelepítési programokat kell meghirdetni, amely átmenetileg javítja a foglalkoztatást, hosszú távon pedig jelentősen növeli ezeknek a térségeknek az ókológiai és gazdasági potenciálját. Gesztorok (termelési rendszerek, nagyưzemek) segítségével támogatni kell a kedvezötlen adottságú térségekben a piacképes árú elóállítására képes extenzív állattartási formák (húsmarha, húsló, juh, szarvas stb.) kialakítását.

- Az ágazat versenyképességének javítása érdekében külön támogatásba kell részesíteni a szőlö- és gyủmőlcsfélék kiváló termöhelyre tơrténő tömbös telepítését és a feldolgozás, tárolás, értékesítés közős megoldását, ahol minden folyamat megfelelö szakirányítással, magas mủszaki színvonalon, kellő ellenőrzés mellett folyik.

- Az állattenyésztés esetében pedig segítséget kell nyújtani a hatékony termelés és a környezet-, valamint az állatvédelem igényeit nemzetkőzi követelményeknek megfelelöen kielégítő telep rekonstrukciókhoz és ezen belul külön súlyt kell helyezni a trágyakezelés és felhasználás korszerű feltételeinek megteremtésére és a követelmények betartását meg is kell követelni.

A korszerü mezőgazdaság egyben környezetkímélő mezőgazdaságot is jelenti, mert a korszerú eszközöket, termelési eljárásokat alkalmazó gazdálkodás illeszkedik az ökológiai adottságokhoz, anyag- és eszkőztakarékos és ezáltal a legkisebb mértékben terheli a kőrnyezetét. A mezőgazdaság versenyképessége hozamban, minőségben, költségben, így egyben az ágazat kơrnyezetkímélő voltát is minősíti. Az agrárpiacokon folyó rendkívül éles verseny az adottságoktól függően egyes térségek intenzifikálását, míg más térségekben a kőltségkímélö termelési módszerek elterjesztését teszi szủkségessé. A magyar mezőgazdaság a jelenlegi állapotában nem tekinthető versenyképesnek sem gazdasági, sem pedig ökológiai szempontból, ehhez az elmúlt tíz év fejlesztési elmaradását pótolni kell. Ez nem kerülhető meg, mert az ország csupán két olyan adottsággal rendelkezik, amelyik a nemzetközi versenyképességét, Nyugat-Európához való betagozódását biztosítja. Az egyik az, hogy egy medence kőzepén, éghajlati övek határán fekszik, amely az agrártermelés számára az átlagosnál jobb feltételeket biztosít, a másik pedig az, hogy Európa közepén, az áruk és emberek mozgásának természetes, történelmileg kialakult útvonalában helyezkedik el, amely a szolgáltatások fejlesztését megköveteli, de egyben gazdaságossá is teszi. Ez az egymásra épülő két feltétel csak akkor jelent gazdasági elönyt, ha mindkettőt a nemzetkőzi szinvonalra lehet emelni, amelyhez szuikséges szellemi tơke az országban rendelkezésre áll. 


\title{
ENVIRONMENTAL AND REGIONAL PROBLEMS OF THE HUNGARIAN AGRICULTURE
}

\begin{abstract}
ATTILA SÁNTHA
It has been hardly more than three decades since Hungarian agriculture abandoned its traditional production model that was very close natural economy. The development and decline of the so-called industry-type model were mainly hindered by a deep crisis induced by politics. Presently the agricultural sector, in which the quality of production and its tools are declining and where the ownerships are chaotic, thus the whole sector becoming less and less competitive, can only meet the market requirements with the help of conscious central interventions. It is important, among other things, because only a dynamically developing sector producing with up-to-date machinery can meet the criteria of environmental and natural protection and also of human health and veterinary hygiene which the society and also the markets expect of agriculture. in Hungary the traditional model contributed to the worsening of the harms with its lack of machinery and poverty, whereas the industry-type model with its extremes and mechanical attitude. Although these latter were significant, they were not as serious as in many developed countries, for the short period of existence of the industry-type model. The biggest problem at the moment is the fact that the Hungarian agriculture is caught in this model because of its crisis, while Western Europe has already left it behind. A run-down sector not only becomes uneconomical but also harmful for the environment. Even in the absence of the necessary tools, the survival of the mechanical, industry-like attitude is a serious problem, demonstrated by the irresponsible use of lands, the abuses in the field of plant protection and the increasing number of stubble-fires.
\end{abstract}

Transiated by Zoltán Raffay 